\title{
Pengaruh Kepatuhan Suplementasi Tablet Kalsium Modifikasi Terhadap Kadar Kalsium dan Tekanan Darah Pada Ibu Hamil
}

\author{
Dhany Dahniarti, Irfan Idris, Nasrudin Am \\ Stikes Yahya Bima \\ Universitas Hasanuddin Makassar \\ Universitas Hasanuddin Makassar \\ dhanydahniarti1@gmail.com \\ Email: irfanfaal@gmail.com \\ Email: ernase@yahoo.co.id
}

\begin{abstract}
Abstrak: Asupan kalsium yang rendah menyebabkan peningkatan tekanan darah tinggi dengan merangsang pelepasan hormone paratiroid dan atau renin yang mengarah terjadinya peningkatan konsentrasi kalsium intra seluler dalam vaskuler sel otot polos dan mengakibatkan vasokonstriksi. Penelitian ini bertujuan untuk mengetahui Mengetahui pengaruh kepatuhan suplemetasi tablet kalsium modifikasi terhadap kadar kalsium dan tekanan darah pada ibu hamil. Penelitian ini dilaksanakan di RSIA Sitti Khadijah I Makassar dengan desain penelitian quasy eksperimen dengan rancangan Pre-post Test Control Group Design. Sampel dalam penelitian ini sebanyak $30 \mathrm{ibu}$ hamil prehipertensi pada usia kehamilan > 20 minggu, 12 ibu hamil yang diberikan tablet kalsium biasa dan 18 ibu hamil yang diberikan tablet kalsium modifikasi masing-masing selama 8 minggu. Analisis data menggunankan uji paired t test. Hasil penelitian menunjukan bahwa adanya perbedaan perubahan kadar kalsium dan tekanan darah pada ibu hamil antara kelompok intervensi dan kontrol dengan nilai $p=0.000 \quad(p<0.05)$. Setelah intervensi rata-rata kanaikan kadar kalsium pada kelompok intervensi 0.4 $\mathrm{mg} / \mathrm{dl}$ sedangkan pada kelompok kontrol $0.1 \mathrm{mg} / \mathrm{dl}$, diikuti dengan rata-rata penurunan tekanan darah sistole dan diastole pada kelompok intervensi 15.4/9.6 mmHg sedangkan pada kelompok kontrol 3.5/4.5 mmHg. Dengan demikian, kelompok yang diberikan tablet kalsium modifikasi lebih efektif meningkatkan kadar kalsium dan menurunkan tekanan darahdibandingkan dengan kelompok yang diberikan tablet kalsium biasa. Kepatuhan suplementasi kalsium sangat mempengaruhi peningkatan kadar kalsium dan penurunan tekanan darah pada ibu hamil.
\end{abstract}

Kata kunci: Kepatuhan, Kalsium, Kadar Kalsium, Tekanan Darah, Ibu Hamil. 


\title{
The Effect Of Compliance Calcium Supplementation modification Tablet On Calcium and Blood Pressure In Pregnant Women
}

\author{
Dhany Dahniarti, Irfan Idris, Nasrudin Am \\ Stikes Yahya Bima \\ Universitas Hasanuddin Makassar \\ Universitas Hasanuddin Makassar \\ dhanydahniarti1@gmail.com \\ Email: irfanfaal@gmail \\ Email: ernase@yahoo.co.id
}

\begin{abstract}
A low intake of calcium leads to an increase in high blood pressure by stimulating the release of paratiroid and renin hormones that lead to increase in intracellular calcium concentration in the vasculer smooth muscle cells and result in vasocontriction. This study aims to determine the influence of compliance to supply modified calcium tablet toward calcium level and blood pressure in pregnant mothers. This research was conducted at RSIA Sitti Khadijah I Maternity Hospital Makassar with research design of quasy experiment with prepost test group control design. There were 30 pregnant mother sampels of prehypertension in gestational age $>20$ weeks, 12 pregnant women were given normal calcium tablets and 18 pregnant women given modified calcium tablets for 8 weeks each. Data analysis use paired t test. The results indicate that there is a different changes of calcium level and blood pressure between pregnant mothers of intervention group and control group with the value of $p=0.000$ $(\mathrm{p}<0.05)$. After intervention averagely the calcium level increase in intervention group $0.4 \mathrm{mg} / \mathrm{dl}$ while in control group $0.1 \mathrm{mg} / \mathrm{dl}$, followed by the average decrease in blood pressure of systole and dyastole in the intervention group 15.4/9.6 $\mathrm{mmHg}$ while in the control group 3.5/4.5 $\mathrm{mmHg}$.
\end{abstract}

Keywords: Compliance, calcium, calcium levels, blood pressure, pregnant women 



\section{Pendahuluan}

Hipertensi dalam kehamilan dinyatakan sebagai kelainan dengan beragam teori (the disease oftheory) yang merefleksikan ketidakpastian sebab dan patofisiologi preeklampsia.Ada beberapa teori yang dikemukakan namun belum ada yang secara pasti mengungkapkan patofisiologi Hipertensi dalam kehamilan (Cunninghamet al., 2010). Dari banyak teori yang telah dikemukakan, tidak ada satu pun teori yang dianggap mutlak benar. Teori-teori tersebut diantaranya adalah (1) teori iskemia plasenta, radikal bebas, dan disfungsi endotel, (2) teori intoleransi imunologik antara ibu dan janin, (3) teori kelainan pada vaskularisasi plasenta, (4) teori adaptasi kardiovaskular, (5) teori defisiensi gizi, dan (6) teori inflamasi (Saifuddin, 2010).

Asupan kalsium yang rendah menyebabkan peningkatan tekanan darah tinggi dengan merangsang pelepasan hormone paratiroid dan atau renin yang mengarah terjadinya peningkatan konsentrasi kalsium intra seluler dalam vaskuler sel otot polos dan mengakibatkan vasokonstriksi. Peranan suplemen kalsium dalam menurunkan gangguan hipertensi dalam kehamilan adalah dengan menurunkan pelepasan kalsium paratiroid dan konsentrasi kalsium intraseluler, akhirnya terjadi penurunan kontraksi otot polos dan peningkatan vasodilatasi (Aamer et al., 2011).

Salah satu program untuk mencegah terjadinya preeklamsi pada ibu hamil yaitu dengan asuhan antenal yang berkualitas dengan cara mendeteksi dini adanya faktor risiko terjadinya komplikasi pada masa kehamilan, persalinan dan nifas. Berdasarkan rekomendasi kuat dari WHO, Indonesia melalui kementrian kesehatan memberikan suplementasi tablet kalsium untuk pencegahan preeklamsia bagi semua ibu hamil terutama yang memiliki resiko tinggi terjadinya preeklamsia dan dengan di area dengan asupan kalsium rendah dengan dosis 1,5-2 gram per hari (Kemenkes, 2013).

Faktor Mineral dan gizi memainkan peran sebagai salah satu etiologi prediksi hipertensi dalam kehamilan. Beberapa studi melakukan penelitian intake kalsium pada kehamilan normal dan kehamilan dengan komplikasi. Terdapat efek yang signifikan pemberian tablet kalsium dan 
vitamin $\mathrm{D}$ pada ibu hamil terhadap tekanan darah, kadar kalsium dan hasil keluaran pada bayi yang dilahirkan (Wuna et al., 2016).

Studi yang lain tekanan pada ibu hamil yang hipertensi setelah konsumsi tablet kalsium terjadi penurunan dengan rerata sistol 4,66 $\mathrm{mmHg}$ dan rerata diastol $6.66 \mathrm{mmHg}$ diikuti juga dengan kadar kalsium pada ibu hipertensi lebih tinggi dengan rerata $0,217 \mathrm{mg} / \mathrm{dl}$ dibandingkan dengan normotensi rerata $0,117 \mathrm{mg} / \mathrm{dl}$ (Wahid et al., 2016).

Penelitian ini bertujuan untuk mengetahui pengaruh kepatuhan suplementasi tablet kalsium modifikasi terhadap kadar kalsium dan tekanan darah pada ibu hamil.

\section{Bahan dan Metode}

\section{Lokasi dan Rancangan Penelitian}

Penelitian ini dilaksanakan dari februari-mei 2017. Lokasi di RSIA Sitti Khadijah1 Makassar. Penelitian ini menggunakan desain quasi eksperimental dengan rancangan pre-post test control group design, dalam penelitian ini akan menggunakan kelompok intervensi yang diberikan suplementasi tablet kalsium modifikasi dan kelompok kontrol yang diberikan tablet kalsium biasa.

\section{Populasi dan Sampel}

Populasi dalam penelitian ini adalah semua ibu hamil usia kehamilan $>20$ minggu di RSIA Sitti Khadijah I Makassar. Jumlah sampel sebesar 30 ibu hamil dengan teknik purposive sampling yang memenuhi kriteria inklusi yaitu ibu hamil usia kehamilan $>20$ minggu disertai tekanan darah sistole $120-139 \mathrm{mmHg}$, tekanan darah diastole $80-80 \mathrm{mmHg}$, tidak disertai dengan penyakit lain dan ibu hamil bersedia menjadi responden dengan menandatangai informed consent yang telah dikeluarkan oleh Komite Etik Fakultas Kedokteran Universitas Hasanuddin.

\section{Metode Pengumpulan Data}

Pengukuran kadar kalsium di klinik prodia dan tekanan darah diperiksa oleh peneliti sendiri dilakukan sebelum diberikan suplemen kalsium modifikasi pada kelompok intervensi dan kalsium tablet pada 
kelompok kontrol. Suplementasi diberikan selama 8 minggu dengan dosis 3x500 mg/hari. Setelah 8 minggu suplementasi tablet kalsium kembali dilakukan pemeriksaan kadar kalsium dan tekanan darah.

\section{Analisis Data}

Dalam penelitian ini data berdistribusi normal. Uji analisis menggunakan uji Paired T Test diolah dengan menggunakan SPSS For Windows 20.

\section{Hasil}

\section{Karakteristik Sampel}

Tabel 1 menunjukkan bahwa 83.3\% responden kelompok Intervensi dal 83.3\% kelompok kelompok berumur antara $<20$ sampai 35 tahun. Sementara itu, berdasarkan karakteristik gestasi 38.9\% kelompok Intervensi dan $41.7 \%$ kelompok kontrol merupakan dengan masa gestasi 21-23 minggu. Berdasarkan karakteristik gravida terdapat 61.1\% kelompok intervensi dan 41.7\% kelompok kontrol merupakan multigravida. Selanjutnya, berdasarkan pekerjaan, responden banyak bekerja sebagai ibu rumah tangga yaitu $61.7 \%$ pada kelompok Intervensi dan $75.0 \%$ pada kelompok kontrol.Tingkat pendidikan rendah 72.6\% kelompok intervensi dan 92.4\% kelompok kontrol.

\section{Kadar Kalsium}

Tabel 2 menunjukkan perubahan kadar kalsium pada ibu hamil sebelum dan sesudah suplementasi tablet kalsium pada kelompok intervensi dan kontrol. Kadar kalsium rerata pada kelompok intervensi dari $8.6 \mathrm{mg} / \mathrm{dL}$ menjadi rerata $9.0 \mathrm{mg} / \mathrm{dL}$ dengan nilai uji statistik ( $p=$ 0.000) maka ada perubahan bermakna sebelum dan sesudah suplementasi tablet kalsium pada kelompok intervensi. Sedangkan kadar kalsium rerata pada kelompok kontrol dari rerata $8.3 \mathrm{mg} / \mathrm{dL}$ menjadi rerata $8.4 \mathrm{mg} / \mathrm{dL}$ dengan nilai uji statistik ( $p=0.399)$, dari hasil tersebut terdapat kenaikan kadar kalsium pada kelompok kontrol tetapi tidak bermakna. Berdasarkan perbandingan nilai kadar kalsium pada kelompok intervensi dan kontrol 
terdapat perbedaan yang bermakna antara kedua kelompok tetapi samasama mengalami kenaikan nilai rerata.

\section{Tekanan Darah}

Tabel 3 menunjukkan memperlihatkan bahwa tekanan darah sistol dan diastol sebelum dan sesudah baik pada kelompok intervensi maupun pada kelompok kontrol mengalami penurunan. Pada kelompok intervensi rerata tekanan darah sistole sebelum suplementasi tablet kalsium modifikasi $130.89 \mathrm{mmHg}$ sedangkan setelah suplementasi $115.44 \mathrm{mmHg}$ dengan hasil uji statistik dengan Uji Paired T Test $(p=0.000$. Sedangkan pada ibu hamil kelompok kontrol juga mengalami penurunan tekanan darah sistol rerata dari $130.33 \mathrm{mmHg}$ menjadi rerata $126.75 \mathrm{mmHg}$ dengan hasil uji statistik yang sama $(p=0.063)$ dan terdapat perbedaan yang bermakna antara kelompok intervensi dan kontrol. Tekanan darah diastole juga penurunan jumlah rerata sebelum dan sesudah suplementasi tablet kalsium baik pada kelompok intervensi maupun pada kelompok kontrol. Tekanan darah diastole dari rerata $83.16 \mathrm{mmHg}$ menjadi 73.55 mmHg pada kelompok intervensi dengan nilai uji statistik Paired_T_Test $(p=0.000)$, sedangkan pada kelompok kontrol tekanan darah diastole dari rerata $81.75 \mathrm{mmHg}$ menjadi $77.25 \mathrm{mmHg}$ dan dilakukan dengan Uji statistik yang sama $(\phi=0.000)$. Dengan demikian tidak ada perbedaan bermakna tekanan darah diastole pada ibu hamil antara kelompok intervensi dan kontrol.

\section{Pembahasan}

Hasil uji statistik dengan uji Paired T Test menunjukkan bahwa terdapat perbedaan rata-rata kadar kalsium antara kedua kelompok. Pada kelompok yang diberikan kalsium modifikasi lebih memberikan efek peningkatan kadar kalsium yang bermakna dibandingkan kelompo. Hasil penelitian menunjukkan bahwa rerata kadar kalsium pada kelompok intervensi dan kelompok kontrol mengalami kenaikan, namun kenaikan kadar kalsium yang bermakna secara statistik hanya pada kelompok intervensi. Hasil ini sejalan dengan penelitian yang dilakukan oleh Berzan et al (2014),bahwa 
suplementasi tablet kalsium signifikan meningkatkan kadar kalsium pada ibu hamil.

Banyak faktor yang mempengaruhi konsentrasi kadar kalsium dalam darah. Adanya penyakit ibu seperti ginjal dan hiperparatiroidisme, kurangnya albumin (protein pengangkut kalsium) dalam darah serta adanya gangguan absorpsi kalsium dapat mempengaruhi kadar kalsium dalam darah, kalsium darah harus seimbang dalam batas normal (Hofmeyr et al., 2015).

Ibu hamil membutuhkan kalsium lebih banyak untuk pertumbuhan janin. Jika asupan kalsium kurang dari kebutuhan tubuh, maka untuk menjaga keseimbangan kadar kalsium darah, hormon paratiroid menstimulasi pengeluaran kalsium dari tulang masuk ke darah. Kalsium dalam darah menjadi menebal dan mengeras sehingga mengurangi elastisitas jantung yang akan meningkatkan tekanan darah (Zuzana et al., 2009 ; Ahsan et al., 2013).

Regulasi kalsium intraseluler memainkan peran kunci dalam hipertensi. Hipertensi diperkirakan merupakan 5\% dari komplikasi seluruh kehamilan dan 11\% terjadi pada usia kehamilan awal. Wanita hamil yang berkembang menjadi preeklamsia berat memiliki intake kalsium yang rendah dibandingkan dengan wanita tensi normal (Yang et al., 2015).

Asupan kalsium yang rendah penyebab tekanan darah tinggi yang dipicu oleh pelepasan hormon paratiroid atau renin yang menyebabkan peningkatan kalsium intraseluler pada vascular otot polos dan memicu vasokontriksi. Aksi dari suplemen kalsium menurunkan pelepasan paratiroid dan intraseluler kalsium dan menyebabkan penurunan kontraktilitas otot polos (Schlembach et al., 2015).

Hasil penelitian ini membuktikan bahwa pemberian suplementasi tablet kalsium dapat meningkatkan kadar kalsium darah pada ibu hamil. Dengan demikian pentingnya pendidikan kesehatan bagi ibu hamil agar program dari kementrian kesehatan pemberian tablet kalsium pada ibu hamil untuk mencegah terjadinya preeklamsia dan eklamsi tepat sasaran. Saat ini penyuluhan tentang pentingnya pemenuhan zat gizi (khususnya kalsium) dalam kehamilan masih kurang dilakukan. Kurangnya pengetahuan tentang pentingnya kalsium memungkinkan ibu hamil tidak mempedulikan konsumsi 
suplemen kalsium yang diberikan oleh bidan. Padahal, kalsium sangat dibutuhkan ibu hamil terutama memasuki masa trimester kedua dan ketiga kehamilan. Pada trimester kedua, pertumbuhan janin akan lebih pesat darpada trimester sebelumnya. Oleh karena itu, ibu hamil lebih banyak membutuhkan kandungan kalsium dibandingakan orang ygang tidak hamil. Kalsium bisa didapatkan dari makanan sumber kalsium seperti sayuran hijau, biji-bijian, kacang-kacangan, daging, telur dan susu. Namun beberapa hasil penelitian menunjukkan bahwa rerata asupan kalsium ibu hamil masih cukup rendah dari angka rekomendasi kebutuhan kalsium ibu hamil yaitu hanya $254 \mathrm{mg} /$ hari dari 1500-2000 mg/hari yang direkomendasikan oleh World Health Organization.

Berdasarkan hasil penelitian, ada perubahan yang bermakna berupa penurunan tekanan darah sistole dan diastole pada kelompok kontrol dan intervensi. Penurunan tekanan darah sistole dan diastole pada kelompok intervensi lebih signifikan dibandingkan dengan kelompok kontrol. Begitu pula dengan tekanan darah diastole pada kedua kelompok mengalami penurunan, namun penurunan yang bermakna secara statistik hanya pada kelompok intervensi.

Sejalan dengan penelitian Anna et al (2014), Ross et al (2011), menjelaskan bahwa Suplemen kalsium selama kehamilan memiliki efek yang signifikan untuk menurunkan resiko preeklamsia. Efek yang menonjol ditunjukkan pada beberapa studi dimana partisipan yang mendapatkan asupan kalsium rendah dibandingkan dengan yang mendapatkan asupan kalsium yang adekuat.

Lebih lanjut, jika ditinjau berdasarkan keteraturan mengkonsumsi tablet kalsium yang teratur lebih signifikan dibandingkan dengan yang tidak baik pada kelompok intervensi maupun kelompok, suplementasi kalsium tampak memberikan efek yang bermakna pada responden yang mengalami prahipertensi tekanan darah sistole dan tekanan darah diastole. Responden prahipertensi diastole mengalami penurunan tekanan darah yang lebih signifikan dibandingkan denga prahipertensi sistol. Walaupun kedua kelompok mengalami perubahan rerata tekanan darah baik sistole maupun diastole. 
Suplementasi tablet kalsium memberikan efek yang baik bagi tekanan darah pada ibu hamil jika dikonsumsi secara teratur sesuai dosis yang dianjurkan.

Penelitian ini menunjukkan bahwa suplementasi kalsium berpengaruh terhadap tekanan darah mengingat kedua kelompok baik kontrol juga mendapatkan suplemetasi kalsium sebagai salah satu program dinas kesehatan dalam mencegah terjadinya preeklamsia pada ibu hamil. Akan tetapi perbedaan tingkat kemaknaan terhadap penurunan tekanan darah antara kelompok kontrol dan intervensi dapat disebabkan oleh kepatuhan atau keteraturan responden mengkonsumsi suplemen kalsium yang diberikan. Pada kelompok intervensi dan kontrol konsumsi suplemen tidak dipantau oleh peneliti atau pembantu peneliti sehingga responden sendiri yang akan mengkonsumsi suplemen sesuai dosis yang diharapkan.

Sejalan dengan penelitian Dharmeizar et al (2012), menjelaskan bahwa asupan kalsium yang rendah menyebabkan peningkatan tekanan darah tinggi dengan merangsang pelepasan hormone paratiroid dan atau renin yang mengarah terjadinya peningkatan konsentrasi kalsium intra seluler dalam vaskuler sel otot polos dan mengakibatkan vasokonstriksi. Peranan suplemen kalsium dalam menurunkan gangguan hipertensi dalam kehamilan adalah dengan menurunkan pelepasan kalsium paratiroid dan konsentrasi kalsium intraseluler, akhirnya terjadi penurunan kontraksi otot polos dan peningkatan vasodilatasi.

Juga dengan Christhoper et al (2012), menyatakan Regulasi kalsium intraseluler memainkan peran kunci dalam hipertensi. Hipertensi diperkirakan merupakan 5\% dari komplikasi seluruh kehamilan dan 11\% terjadi pada usia kehamilan awal. Wanita hamil yang berkembang menjadi preeklamsia berat memiliki intake kalsium yang rendah dibandingkan dengan wanita tensi normal.

\section{Kesimpulan}

Terdapat perbedaan rerata peningkatan kadar kalsium antara kelompok intervensi (kalsium modifikasi) dan kelompok kontrol (kalsium biasa). Terdapat perbedaan rerata penurunan tekanan darah sistole dan diastole antara kelompok intervensi (kalsium modifikasi) dan kelompok kontrol 
The Effect Of Compliance Calcium Supplementation modification Tablet On Calcium and Blood Pressure In Pregnant Women

(kalsium biasa). Kepatuhan dalam suplementasi tablet kalsium modifikasi dapat meningkatkan kadar kalsium dan menurunkan tekanan darah pada ibu hamil prehipertensi. 


\section{Daftar Pustaka}

Aamer I., Afsan J., Julfiqar A. (2011). Role of calcium supplementation during pregnancy in reducing risk of developing gestational bypertensive disorders: a metaanalysis of studies from developing countries. BMC public health 11. suppl 3. S18.

Ahsan T. et al. (2013). Serum Trace Elements Levels in Preeclampsia and Eclampsia: Correlation with the Pregnany Disorder. Biol Trace Elem Res 152. 327-332.

Anna B. et al. (2014). Tablets Are Preferred and More Acceptable Than Powdered Prenatal Calcium Supplements among Pregnant Women in Dhaka Bangladesh. American Society fot nutrition 144. 1106-1112.

Berzan E. et al. (2014). Treatment of Preeclampsia. Current Approach and Future Perspectives. Curr Hypertens. 16.473.

Christhoper S. et al. (2012). Calcium metabolism during pregnancy and lactation. Faculty of medicine-endokrinologi. University of Newfoundland. Chapter 3.

Cunningham FG., Gant NF., Leveno KJ., Gilstrap LC., Hauth JH., Wenstrom KD. (2010). Pregnancy Hypertention. Williams obstetrics. 23rd edition. McGrawHill. New York : 706-738.

Dharmeizar et al. (2012). Hipertention. Medicus Scientific Journal Of Pharmaceutical Development and Medical Application. 3-8.

Hofmeyr ., Atallah., Duley. (2015). The effect of calcium supplementation on blood pressure in non-pregnant women with previous pre-eclampsia: An exploratory, randomized placebo controlled study. Journal of Women's Cardiovascular Health. 273-279.

Kemenkes RI. (2013). Buku saku pelayanan kesehatan ibu difasilitas kesehatan dasar dan rujukan. Jakarta.

Ross A. et al. (2011). Dietary reference intake CalciumVitamin D. Washington, D.C.: The National Academies Press.

Saifuddin AB. (2010). Ilmu kebidanan. Edisi keempat. Jakarta: Yayasan bina pustaka Sarwono Prawirohardjo.

Schlembach D. et al. (2015). Treating Hypertension in Pregnancy. Cur Hypertens rep. 17:63.

Wahid N. et al. (2016). Hubungan konsumsi tablet kalsium terhadap tekanan darah pada ibu hamil di RSUD Pangkep. Makassar: Universitas Hasanuddin. 
Wuna W. et al. (2016). Efek pemberian suplemen kalsium dan vitamin D pada ibu hamil hipertensi terhadap outcome kehamilan di Puskesmas Kota Kendari. Makassar: Universitas Hasanuddin.

Yang N. et al. (2015). Effects of vitamin D supplementation during pregnancy on neonatal vitamin $D$ and calcium concentrations a systematic review and meta-analysis. Nutrition research 35. 546-556.

Zuzana A., Sifa O., Razif A. (2009). Vascular and cellular calcium in normal andhypertensive pregnancy. Curr Clin Pharmacol 1.23-28.

Tabel 1. Karakteristik Resoponden Ibu Hamil

Kelompok

Karakteristik Responden

Intervensi Kontrol

$\mathrm{n}=18 \quad \mathrm{n}=12 \quad \%$

\begin{tabular}{lcccc}
\hline Umur & & & & \\
& 15 & 83.3 & 10 & 83.3 \\
$<20-35$ tahun & 3 & 16.7 & 2 & 16.7
\end{tabular}

\section{Gravida}

Primigravida

$\begin{array}{lll}7 & 38.9 & 7\end{array}$

58.3

Multigravida

$11 \quad 61.1 \quad 5$

41.7

\section{Usia Kehamilan}

21-23

24-25 $\begin{array}{llll}7 & 38.9 & 5 & 41.7\end{array}$

$\begin{array}{llll}4 & 22.2 & 4 & 33.3\end{array}$ 


\begin{tabular}{lllll}
\hline$>25$ & 7 & 38.9 & 3 & 25.0
\end{tabular}

\section{Pendidikan}

Rendah

Tinggi

\section{Pekerjaan}

$\begin{array}{lcccr}\text { PNS } & 2 & 11.1 & 1 & 8.3 \\ \text { Honorer } & 2 & 11.1 & 1 & 8.3 \\ \text { Swasta } & 2 & 11.1 & 1 & 8.3 \\ \text { IRT } & 12 & 66.7 & 9 & 75.0\end{array}$

Sumber : Data Primer 2017

Tabel 2. Perubahan Kadar Kalsium pada Kelompok Intervensi dan Kontrol

\begin{tabular}{ccccc}
\hline Kadar Kalsium & $\mathbf{n}$ & Pre & Post & $P$ \\
& & $8.6444 \pm 0.4$ & $9.0944 \pm 0.3$ & 0.000 \\
\hline Intervensi & 18 & & & \\
Kontrol & 12 & $8.3167 \pm 0.6$ & $8.4417 \pm 0.7$ & 0.399
\end{tabular}

Sumber : Data Primer 2017

Tabel 3. Perubahan Perubahan Tekanan Darah pada Kelompok Intervensi dan Kontrol

\begin{tabular}{ccccc}
\hline Tekanan & \multicolumn{3}{c}{ Mean \pm SD } \\
Darah & N & Pre & Post & $P$ \\
$(\mathrm{mmHg})$ & & & & \\
\hline
\end{tabular}

Intervensi 
Hubungan Perilaku Merokok Terhadap Penurunan Nafsu Makan (Anoreksia) Pada Mahasiswa S1 Keperawatan Stikes Yahya Bima

$\begin{array}{lrrrr}\text { Sistole } & 18 & 130.89 \pm 5.0 & 115.44 \pm 8.5 & 0.000 \\ \text { Diastole } & 18 & 83.1667 \pm 3.0 & 73.5556 \pm 4.8 & 0.000\end{array}$

Kontrol

$\begin{array}{lllll}\text { Sistole } & 12 & 130.33 \pm 7.0 & 126.75 \pm 6.3 & 0.063\end{array}$

$\begin{array}{lllll}\text { Diastole } & 12 & 81.7500 \pm 3.6 & 77.2500 \pm 3.8 & 0.000\end{array}$

Sumber : Data Primer 2017 